\title{
TINJAUAN HUKUM ISLAM TERHADAP PRAKTEK ARISAN BERANAK (Studi Kasus Desa Sidorejo KecamatanWonomulyo)
}

\author{
Ratnasari, Muhammad Nuzur \\ Prodi Hukum Ekonomi Syariah, Fakultas Agama Islam, Universitas Al Asyariah Mandar \\ ratnarat295@gmail.com
}

\begin{abstract}
Abstrak
Fokus masalah dari penelitian ini adalah bagaimana praktek arisan beranak berupa uang pada setiap pengundian terdapat tambahan di Desa Sidorejo Kecamatan Wonomulyo dan bagaimana tinjauan hukum Islam terhadap praktek arisan beranak yang dipersyaratkan dalam setiap pengundian di Desa Sidorejo Kecamatan Wonomulyo. Jenis penelitian ini tergolong kualitatif deskriptif dimana peneliti yang turun langsung ke lokasi penelitian. Pendekatan yang digunakan dalam penelitian adalah pendekatan syar'i dan pendekatan sosial. Sedangkan sumber data dari penelitin ini yaitu sumber data primer dan sekunder. Tehnik pengolahan data dalam penelitian ini meliputi observasi, wawancara dan dokumentasi. Instrumen penelitian adalah peneliti itu sendiri. Pengujian keabsahan data dalam penelitian ini menggunakan trigulasi. Hasil dari penelitian ini menunjukkan bahwa praktek arisan beranak yang ada di Desa Sidorejo Kecamatan Wonomulyo menggunakan akad hutang-piutang. Yang beruntung dan yang berpiutang yaitu mereka yang mendapatkan undian arisan lebih awal adalah sebagai yang berhutang (kreditur) karena mereka harus membayar uang setoran beserta tambahannya setiap bulan kepada mereka yang belum mendapatkan. Dan yang berpiutang (debitur) adalah anggota yang mendapat arisan lebih akhir karena mereka memberikan pinjaman kepada anggota yang mendapat undian terlebih dahulu. Pandangan hukum Islam terhadap tambahan dalam praktek arisan beranak tersebut sama dengan riba dalam hutang-piutang. Karna terdapat tambahan yang telah disepakati pada awal di dirikan arisan, tambahan tersebut meningkat sedikit demi sedikit setiap bulannya. Implikasi dalam penelitian baiknya apabila ada tambahan dalam praktek arisan beranak ini menggunakan akad mudharabah. Setiap anggota mendapat bagian dari keuntungan pekerjaan yang mendapatkan undian terlebih dahulu. Hanya memberikan tambahan yang kecil apabila bahan pokok mengalami kenaikan agar tidak memberatkan para pelaku arisan dengan tambahan yang terus meningkat setiap bulan.
\end{abstract}

Kata kunci: Hukum Islam, Arisan Beranak.

\begin{abstract}
The focus of the problem of this research is how the practice of arisan with children in the form of money is added in Sidorejo Village, Wonomulyo District and how Islamic law reviews the practice of arisan with children required in each lottery in Sidorejo Village, Wonomulyo District. This type of research is classified as a descriptive qualitative where researchers who go directly to the research location. The approach used in the research is the syar'i approach and the social approach. While the data sources of this research are primary and secondary data sources. Data processing techniques in this study include observation, interviews and documentation. The research instrument is the researcher himself. Testing the validity of the data in this study using trigulation. The results of this study indicate that the practice of social gathering for children in Sidorejo Village, Wonomulyo District uses debt-receivable contracts. Those who are lucky and those who are in debt, namely those who get the arisan lottery early are the debtors (creditors) because they have to pay the deposit and additional monthly payments to those who have not received it. And those who have debts (debtors) are members who get the arisan later because they provide loans to members who get the lottery first. The view of Islamic law on the addition in the practice of arisan for children is the same as usury in debts. Because there are additions that have been agreed upon
\end{abstract}


at the beginning of the arisan, the additions increase little by little every month. The implications of the research are good if there is an addition to the practice of this social gathering using a mudharabah contract. Each member gets a share of the profits of the job that gets the lottery first. Only providing a small addition if the basic ingredients increase so as not to burden the arisan actors with additional items that continue to increase every month.

Keywords: Islamic Law, Arisan Beranak.

\section{PENDAHULUAN}

Dalam kehidupan manusia di dunia ini untuk menjalankan kehidupan tidak dapat dipisahkan dari kebutuhan baik kebutuhan pokok maupun kebutuhan tambahan. Untuk mengatasi masalah kehidupan, orang tidak bisa melakukannya sendiri tetapi membutuhkan orang lain. Sudah menjadi naluri manusia yang diciptakan oleh Allah SWT untuk saling membutuhkan. Sehingga dapat saling membantu, memperdagangkan kebutuhan dalam segala persoalan kehidupan, baik dengan jual beli, sewa menyewa, piutang, budidaya atau lainnya. Dengan koneksi yang begitu kecil di arena publik, maka, pada saat itu kami mencari cara untuk saling membantu sejauh melihat satu sama lain. Keterkaitan antara hak dan komitmen dalam aktivitas publik disebut hukum muamalah.

Bermuamalah sangat dianjurkan dalam Islam, dan dalam muamalah harus dengan cara yang halal dan bijaksana, sehingga individu yang melakukan muamalah tidak merasa tersakiti dan tidak menyakiti orang lain. Dalam muamalah terdapat keputusan-keputusan yang sebagian besar bersifat wajar dan juga bersifat umum. Jadi dalam muamalah harus dengan individu yang karakternya jelas sehingga individu memiliki rasa aman dan tidak stres atas dukungannya. Ini dengan tujuan agar orang mencapai yang paling ekstrem dari apa yang diharapkan secara umum.

Manusia adalah makhluk hidup yang mempunyai kebutuhan hidup yang beraneka ragam dan kompleks. Maka dari itu manusia memerlukan bantuan orang lain dalam memenuhi kebutuhan hidupnya. Dalam rangka memenuhi kebutuhan hidupnya tersebut manusia melakukan aktifitasaktifitas kerja sama dengan orang lain. Di dalam hukum Islam sudah diatur mengenai aturanaturan tertentu, agar tidak terjadi ketimpangan-ketimpangan yang bisa menyebabkan bentrokan antar berbagai kepentingan. Aturan-aturan atau patokan-patokan yang mengatur tentang hubugan hak dan kewajiban dalam hidup bermasyarakat itu disebut dengan hukum muamalah. ${ }^{1}$

Orang diberi kesempatan yang kuat dalam mengelola semua bagian kehidupan yang fleksibel dan membantu, selama mereka tidak bergumul dengan tulisan-tulisan yang direkomendasikan Al-Qur'an dan Syara', untuk secara konsisten menjaga keseimbangan hak. juga, komitmen individu yang diinvestasikan untuk membuat ekuitas dan memiliki rasa aman dan tidak merasa dirugikan.

Kebutuhan material manusia diciptakan sesuai dengan kemajuan budaya manusia itu sendiri, manusia diberi kesempatan dalam memenuhi kebutuhannya, kesempatan tidak langsung, namun kesempatan bukanlah yang utama, kesempatan dibatasi oleh orang yang berbeda.

Upaya untuk mengatasi masalah materi, saat ini banyak orang yang berlatih arisan. Dari perspektif keseluruhan, arisan atau dana investasi umum adalah bermacam-macam uang tunai yang ditarik secara rutin. Pada afiliasi, setiap bagian harus bergabung dan juga harus menyimpan sejumlah uang tertentu yang telah diselesaikan. Takaran uang tunai yang terkumpul kemudian diberikan kepada individu yang mendapat undian. Juga, di bulan berikutnya anggota yang mendapatkan lotre benar-benar membayar toko sehingga individu yang berbeda mendapat giliran dalam lotre. Dll, sehingga semua individu yang terdaftar di afiliasi mendapatkan undian.

1 Ahmad Azhar Basyr, Asas-asas Hukum Muamalat, edisi revisi, (Yogyakarta Perpustakaan Fakultas Hukum UII,1993), h.7. 
Apalagi kumpul-kumpul merupakan salah satu jenis muamalah yang pasti dan terkenal di masyarakat yang dalam penerapannya memiliki beragam cara, misalnya: pesta sebagai uang tunai, produk, rasa dan lain-lain. Namun yang sering dialami dan sebagian besar dilakukan oleh daerah adalah kumpul-kumpul dalam bentuk uang, pesta semacam ini tidak diperbolehkan.

Manusia adalah makhluk hidup yang memiliki kebutuhan hidup yang beragam dan kompleks. Sepanjang garis ini, orang membutuhkan bantuan orang lain dalam memenuhi kebutuhan mereka. Untuk mengatasi masalah hidupnya, orang menyelesaikan latihan kooperatif dengan orang lain. Dalam hukum Islam, prinsip-prinsip tertentu telah diarahkan, sehingga tidak ada hal-hal yang diidentikkan dengan kepentingan yang berbeda. pedoman atau prinsip yang mengatur mengandung kerentanan taruhan. Patut diperhatikan bahwa kumpul-kumpul adalah sesuatu yang khas yang sering dijumpai dalam tatanan sosial yang pluralistik sebagai gerakan finansial.

Arisan merupakan aksi sosial yang dimanfaatkan sebagai media untuk saling mengunjungi, saling mengenal, saling memberi dan membutuhkan, hanya sebagai wahana silaturahmi. Dalam kaitannya dengan urusan keuangan, arisan adalah organisasi yang dilindungi secara kebetulan yang pada tingkat dasar, arisan adalah kewajiban yang berfungsi sebagai tempat untuk dana investasi dan kredit.

Afzalurrahman berpendapat bahwa setiap anggota arisan memiliki dua pekerjaan, yaitu sebagai pemberi pinjaman sekaligus sebagai pemegang utang. Selain itu, konon, masyarakat saat ini menganggap bunga sebagai hal yang penting dan pasti bagi kegiatan kerangka moneter daerah. Dengan cara ini, faktor-faktor mengambil bagian yang besar dan dominan dalam menentukan mentalitas kita (masyarakat saat ini). ${ }^{2}$

Kemudian lagi, tindakan arisan dengan anak-anak di Kota Sidorejo, Kabupaten Wonomulyo, khususnya memberikan tambahan simpanan bulan ke bulan, perlu dicermati status halalnya dalam Islam karena kenaikan yang diperlukan. Sehubungan dengan pelaksanaan arisan ini, anggotanya terdiri dari warga Kota Sidorejo, Wilayah Wonomulyo, yang mengundi arisan satu kali dalam sebulan.

Di daerah tempat tinggal sang pencipta, ada beberapa kelompok yang mengamalkan amalan kumpul-kumpul, di mana pelaku yang mengikuti amalan pesta itu sebagian besar beragama Islam. Oleh karena itu, para kreator tertarik untuk mendalami Survei Hukum Islam tentang Akta Arisan Beranak, khususnya di masyarakat Desa Sidorejo, Kecamatan Wonomulyo.

\section{METODE PENELITIAN}

Metode yang digunakan dalam penelitian ini adalah deskriptif-kualitatif yaitu menggambarkan karakteristik masyarakat terhadap fenomena sosial yang bersifat unik dan kompleks. Data atau informasi harus ditelusuri seluas-luasnya sesuai yang ada berupa informasi lisan dari beberapa orang yang dianggap mengetahui secara dalam tentang Praktek Arisan Beranak yang akan diteliti. Lokasi penelitian ini dilaksanakan di Desa Sidorejo Kecamatan Wonomulyo. Adapun pendekatan penelitian yang digunakan dalam penelitian ini adalah pendekatan syar'i dan pendekatan sosial. Sumber data penelitian ini adalah data primer dan sekunder. Metode pengumpulan data yang digunakan dalam penelitian ini yaitu observasi, wawancara dan dokumentasi. Instrumen dalam penelitian ini adalah peneliti itu sendiri. teknik pengolahan data yang digunakan metode induktif, deduktif dan campuran. Analisis data bisa dimulai dengan membaca transkip wawancara atau mendengar kembali hasil wawancara, catatan lapangan, atau

\footnotetext{
${ }^{2}$ Afzalurrahman, Doktrin Ekonomi Islam, (Yogyakarta: Dana Bhakti Wakaf, 1995). h.
} 189. 
dokumen yang perlu dianalisis dalam penelitian kualitatif bisa dilakukan sebelum dan sesudah berada ditempat penelitian berlangsung.

\section{HASIL PENELITIAN}

\section{A. Praktek Arisan Beranak di Desa Sidorejo Kecamatan Wonomulyo}

Manfaat arisan ini disamping kebutuhan finansial juga bisa sbagai wadah silahturahmi. Menyambung silahturahmi memberi manfaat yag besar pertama memudahkan rejeki dan kedua memanjangkan umur. Silaturahmi yang terjalin dengan baik tentunya membantu masyarakat untuk hidup rukun dan damai. ${ }^{3}$

Dari perspektif keseluruhan, arisan atau dana cadangan bersama adalah bermacammacam uang tunai yang ditarik secara rutin. Salah satu latihan arisan yang dilakukan oleh daerah di Desa Sidorejo, Kecamatan Wonomulyo, adalah arisan dengan kerangka tambahan atau dikenal di kalangan masyarakat setempat. ialah arisan beranak, yang mana arisan dilaksanakan setiap sebulan sekali hingga arisan selesai. Berikut ini wawancara penulis dengan salah satu ketua arisan beranak yaitu Ibu Martini dengan mengatakan:

"Saya mendirikan arisan agar mempunyai simpanan kedepannya, atau bisa saya pake untuk modal berdagang dan usaha yang lain atau kalo saya butuh uang tiba-tiba tidak punya kan saya punya simpanan uang arisan saya dan itu cukup membatu saya". ${ }^{4}$

Kemudian Peneliti melakukan wawancara dengan anggota yang mengikuti arisan yaitu Ibu Sulami dengan mengatakan bahwa:

"Waktu baru muncul ini arisan orang-orang disini masih menggunakan bahan pokok, seperti terigu, mie, gula, minyak dan beras karena arisan yah digunakan saja seperti bantu-bantu tetangga kalo ada acaranya, tapi sekarang beda mi pake uang mi orang". 5

Dari hasil wawancara di atas dapat dipahami bahwa tujun didirikannya arisan ini agar mereka mempunyai simpanan untuk kedepannya, atau nanti bisa juga digunakan sebagai tambahan modal usaha. Ketika mengikuti arisan mereka mampu mengontrol pemakaian uang sehari-hari agar uangnya bisa tersimpan dan tidak foya-foya sebab mereka masih terikat dengan orang lain. Berikut ini wawancara penulis dengan salah satu anggota arisan beranak yaitu Ibu Tiah berpendapat:

"kalo saya terus terang kan ada tambahannya itu agak banyak karna sayakan ikut tiga, kalo masih awal-awal itu sedikit, nanti kalo sudah pertengahan keatas ya lumayan banyak. Tapi yah tidak apa-apa karna sudah tau memang dari awal arisan toh, apalagi bisa pake modal kedepan. Jadi kalo yang dapat terakhir lebih banyak yah sudah rejekinya dia karna kita juga sudah dikasi modal duluan". 6

${ }^{3}$ Saifuddin, J-Alif Jurnal Penelitian Hukum Ekonomi Syariah, Praktek Bangung Rumah Tinggal Dengan Sistem Arisan Dalam Tinjauan Hukum Islam, (Lembaga Penelitian dan Pengabdian Masyarakat Universitas Al Asyiariah Mandar,2017)

${ }^{4}$ Martini, Ketua Praktek Arisan Beranak Desa Sidorejo, Kec. Wonomulyo, Wawancara oleh penulis di Desa Sidorejo, 20 April 2021, Jam 13.00

${ }^{5}$ Sulami, Anggota Praktek Arisan Beranak Desa Sidorejo, Kec. Wonomulyo, Wawancara oleh penulis di Desa Sidorejo, 26 April 2021, Jam 10.00

${ }^{6}$ Tiah, Anggota Praktek Arisan Beranak Desa Sidorejo, Kec. Wonomulyo, 26 April 2021, Jam 15.00. 

bahwa:

Wawancara penulis dengan Ketua Praktek Arisan Beranak Ibu Martini berpendapat

“ Kalau kita perlu sekali uang untuk acara atau keperluan mendesak kan bisa pake uang arisan, seumpama kita perlunya sekarang terus bukan namata yang keluar digoncangan, sebelumnya bisa baku atur sama yang namanya keluar untuk dipake duluan kalo orangnya mau". ${ }^{7}$

Kemudian wawancara peneliti dengan anggota yang mengikuti arisan yaitu Ibu Sulami yang mengatakan bahwa:

"Kalau arisan kan tidak selamanya enak juga, kan namanya juga utang toh, tapi kalo tidak begini yah tidak punya simpanan juga".

Kemudian wawancara peneliti dengan anggota yang mengikuti arisan yaitu Ibu Ngadiem yang mengatakan bahwa:

"Kalau saya tidak masalah ada tambahannya, karena yang keluar pertama sudah dikasi modal duluan, istilahnya itu yang keluar terakhir itu kayak bonusnya dia". ${ }^{9}$

Awal mula tujuan di dirikannya arisan oleh sebahagian masyarakat digunakan sebagai penyambung tali silaturahmi sesama mereka, dan dalam konsep yang lain digunakan untuk membatu sesama warga sekitar apabila seorang warga mempunyai kendala dalam melaksanakan kegiatan tersebut maka uang dari arisan ini dapat membatunya. Namun seiring berkembangnya zaman arisan digunakan sebagai ladang bisnis oleh sebahagian masyarakat untuk mengembangkan uang.

Dalam kesempatan lain peneliti melakukan wawancara kepada responden yaitu Ibu Ngadiem salah satu anggota arisan yang mengatakan bahwa:

"Sebelum arisan ini di undi pertama-tama yang pegang arisan harus pastikan dulu semua anggota arisan yang masuk sudah semua membayar supaya orang yang naik arisannya bisa langsung diambil uangnya". ${ }^{10}$

Dan selanjutnya wawancara penulis dengan Ibu Martini ketua praktek arisan beranak yang menuturkan pendapatnya bahwa:

"Arisan beranak ini nama anggotanya 30 orang cuman itu ada yang ikut satu, dua bahkan juga tiga cuman namanya beda-beda, baru rata-rata yang ikut itu cuman orang-orang disini karna jangan sampai nanti kalo orang jauh takutnya nanti susah bayarnya. Disini setiap arisan itu digoncang naik seribu perbulannya, cuman kalo pertama itu masih normal". ${ }^{11}$

${ }^{7}$ Martini, Ketua Praktek Arisan Beranak Desa Sidorejo, Kec. Wonomulyo, 20 April 2021, Jam 13.00

${ }^{8}$ Sulami, Anggota Praktek Arisan Beranak Desa Sidorejo, Kec. Wonomulyo, 26 April 2021, Jam 10.00

9 Ngadiem, Anggota Praktek Arisan Beranak Desa Sidorejo, Kec. Wonomulyo, Wawancara oleh penulis di Desa Sidorejo, 27 April 2021, Jam 15.30 2021, Jam 15.30

${ }^{10}$ Ngadiem, Anggota Praktek Arisan Beranak Desa Sidorejo, Kec. Wonomulyo, 27 April

${ }_{11}$ Martini, Ketua Praktek Arisan Beranak Desa Sidorejo, Kec. Wonomulyo, 20 April 2021, Jam 13.00 
Dan selanjutnya wawancara penulis dengan Ibu Sulami selaku anggota praktek arisan beranak yang mengatakan bahwa:

"Dari 30 orang yang ikut arisan sudah 21 orang yang dapat undian". ${ }^{12}$

Dari hasil wawancara di atas bahwa anggota yang ikut dalam praktek arisan beranak sudah 21 orang yang namanya telah mendapat undian. Dan sebelum melakukan pengundian arisan maka ketua arisan memastikan semua anggota arisan telah selesai membayar arisannya karena saat pengundian arisan di mulai maka yang naik undiannya akan mendapatkan uang tersebut dan langsung serah terima. Namun di sisi lain, arisan beranak ini memiliki tiga puluh (30) orang anggota yang terdiri dari warga Desa Sidorejo itu sendiri, dan proses pembayaran arisan ini dimana setiap orang wajib menyetorkan Rp 100.000 iuran perbulan, di bulan pertama saat arisan dimulai perbayarannya normal akan tetapi pada bulan selanjutnya memiliki kelipatan Rp 1000, begitu pula di bulan berikutnya bertambah menjadi Rp.2000 dan seterusnya.

Agar bisa lebih mudah memahami maka peneliti membuat gambaran jalannya arisan beranak yang berlaku di kalangan masyarakat Desa Sidorejo Kecamatan Wonomulyo sebagai berikut:

1. Pada pertemuan arisan pertama, setiap bagian menghemat Rp. 1.000 .000 untuk setiap individu dan member yang namanya keluar dari undian utama tidak mendapatkan tambahan uang yaitu masih Rp. 3.000.000

2. Pada pertemuan arisan kedua, setiap bagian menghemat Rp. 1.000 .000 atau lebih Rp. 1.000 untuk setiap individu dan digandakan oleh dua puluh (30) individu, maka pada saat itu toko yang terkumpul menjadi Rp. 3.030.000.

3. Pada pertemuan ketiga, setiap bagian dihemat sejumlah Rp. 100.000 untuk setiap individu, dan dikalikan dengan Rp 2.000. 2000 menjadi Rp. 60.000. Kemudian, pada saat itu toko yang terkumpul menjadi Rp. 3.060.000.

4. Pada pertemuan pihak keempat, setiap bagian menghemat Rp. 100.000 untuk setiap individu, dan ditambah $\mathrm{Rp}$ 3.000. 3.000 hingga Rp. 90.000. Kemudian, pada saat itu toko yang terkumpul menjadi Rp. 3.090.000.

5. Pada pertemuan arisan kelima, setiap bagian disimpan Rp. 100.000 untuk setiap individu, dan ditambah Rp 4.000. 4.000 hingga Rp. 120.000. Kemudian, pada saat itu toko yang terkumpul menjadi Rp. 3.120.000.

Arisan seperti ini merupakan hal yang umum dan sudah menjadi kecenderungan bagi masyarakat Desa Sidorejo untuk dilakukan dengan alasan bahwa standar konversi rupiah untuk suatu periode akan berkurang dengan mengorbankan sesuatu. Terlebih lagi, selisih 1.000 rupiah setiap bulannya meskipun jangka waktu yang sangat ketat untuk menarik arisan langsung ditarik, tanpa mengetahui peningkatan standar konversi rupiah perputaran uang dalam kehidupan individu. Begitulah arisan dengan kerangka biaya melahirkan yang berlangsung di kalangan warga Desa Sidorejo, Kecamatan Wonomulyo, Rezim Polewali Mandar.

Selanjutnya adalah pertemuan pencipta dengan salah satu pejabat dari Desa Sidorejo, Kcamatan Wonomulyo, Dwi Widodo yang berpendapat bahwa:

"Jika masyarakat mengikuti arisan justru bagus karna selain sebagai simpanan untuk dimasa mendatang, juga semakin mempererat tali silaturahmi. Tapi mengenai tambahan dalam arisan tersebut jika selama itu tidak memberatkan pelaku arisan tidak masalah. Akan tetapi jika itu sudah memberatkan bisa berdampak buruk untuk ekonomi

${ }^{12}$ Sulami, Anggota Praktek Arisan Beranak Desa Sidorejo, Kec. Wonomulyo, 26 April 2021, Jam 10.00 
masyarakat itu sendiri. Dikarnakan arisan sama dengan hutang, dimana kita dipinjamkan oleh orang lain". ${ }^{13}$

Dari hasil wawancara diatas arisan cukup berperan baik dalam ekonomi masyarakat selagi masyarakat tidak keberatan dengan tambahan yang telah ditetapkan dari awal arisan didirikan, tetapi jika masyarakat telah terbebani dengan tambahan tersebut, maka akan berdampak buruk bagi masyarakat itu sendiri.

\section{B. Tinjauan Hukum Islam Terhadap Praktek Arisan Beranak di Desa Sidorejo, Kecamatan Wonomulyo.}

Dalam keberadaan manusia, baik secara mandiri atau dalam kelompok, mereka umumnya berusaha untuk memenuhi kebutuhan mereka sehari-hari. Dengan berbagai macam kebutuhan, masyarakat juga memiliki banyak cara untuk memenuhi kebutuhan mereka, Islam juga sangat menyukai orang untuk berusaha memenuhi kebutuhan mereka. Selain itu, Islam juga merupakan individu untuk berbaur dan berkomunikasi dengan orang lain. Salah satu upaya daerah untuk mengatasi masalah mereka adalah dengan latihan pesta.

Arisan merupakan salah satu cara untuk membantu memenuhi kebutuhan manusia yang secara rutin dilakukan dengan berkumpulnya individu-individu. Arisan juga bisa meringankan beban, meski bagi orang yang berada di bawah bantuan tetangganya, mereka belum bisa menyetujui aturan syariat Islam. Bagaimanapun, dengan bantuan ini, cukup untuk meringankan beban individu yang membutuhkan bantuan tersebut. Meski bantuan yang kita berikan kepada orang yang membutuhkan tidak banyak, ia harus bergembira karena ia mendapat sedikit bantuan. Arisan juga dapat disebut kewajiban, karena dalam tindakan arisan terdapat pemberi pinjaman dan peminjam.

Hal itu terjadi pada masyarakat Desa Sidorejo Kecamatan Wonomulyo. Para warga sekitar melakukan praktek arisan dengan pengundian setiap bulan. Namun sudah dijelaskan sebelumnya bahwa arisan yang didirikan masyarakat di Desa Sidorejo mengalami kenaikan setiap bulannya yakni Rp. 1000/bulan hingga Rp. 30.000 dan harus dibayar tambahan tersebut setiap bulannya.

Berikut adalah hasil wawancara yang dilakukan Penulis dengan Tokoh Agama mengenai tambahan dalam praktek arisan beranak di Desa Sidorejo Kecamatan Wonomulyo oleh Bapak Usman Qultubi”

"Kalau hukum arisan masing-masing ulama berbeda pendapat, ada yang membolehkan ada juga yang tidak. Awalnya itu mubah atau boleh, karena arisan sama dengan muamalah duniawiah. Cuman kita harus menjaga praktek atau sistemnya, karena sistemlah yang membuat arisan itu halal atau haram. Jadi, kalau seperti yang telah dijelaskan adanya penambahan, dalam hukum Islam apapun itu namanya kalau sudah ada semacam bunga atau tambahan yang telah disepakati di awal, maka itu diharamkan karena sama dengan Riba. Sedikit banyaknya tambahan dalam sebuah transaksi itu adalah hukumnya Haram.”14

Berdasarkan hasil wawancara diatas masing-masing ulama berbeda pendapat ada yang mengatakan boleh dan ada yang tidak, namun hukum awalnya mubah (boleh). Sedangkan pada

${ }^{13}$ Dwi Widodo, Aparat Desa Sidorejo, Kec. Wonomulyo, Wawancara oleh penulis di Desa Sidorejo, 11 juni 2021, Jam 09.30.

${ }^{14}$ Usman Qultubi, Tokoh Agama Desa Sidorejo, Kec. Wonomulyo, Wawancara oleh penulis di Desa Sidorejo, 11 juni 2021, Jam 04.30 
hasil penelitian tentang praktek arisan beranak yang berjalan di Desa Sidorejo Kecamatan Wonomulyo seperti arisan pada umumnya. Namun mereka melakukan pinjaman berbunga keseluruh anggota yang mengikuti arisan. Dan arisan yang mereka lakukan berupa hutang-piutang antara anggota arisan itu sendiri. Pencipta tidak yakin untuk meningkatkan uang dalam arisan, ada keuntungan dalam pertukaran arisan yang diselesaikan menjelang awal pemahaman. Setiap bagian harus menambah kontribusi dalam setiap pertemuan arisan, dengan pilihan yang sangat besar. Terlebih lagi, toko tambahannya unik, semakin lama arisan, semakin menonjol opsi yang harus ditambahkan dan semakin penting nilai arisan yang didapat. Perluasan tindakan arisan untuk memiliki anak dalam Islam disebut Riba.

Riba dalam arti sebenarnya mengandung makna: ekstra (yizadah). Menurut hukum Islam, riba adalah suatu ekspansi sebagai uang tunai, produk, atau administrasi, yang mengharuskan peminjam untuk membayar sejumlah uang tunai yang dipinjamkan, kepada pemberi pinjaman, pada hari ketika uang itu dikembalikan.

Mengingat penjelasan sub pasal dalam akta arisan, anak-anak dilimpahkan riba nasi'ah, yang mengandung arti tambahan yang diperlukan diambil atau diperoleh dari orang yang berada di bawah air sebagai pembayaran atas keterlambatan penggantian.

Larangan keras membakar-melalui riba telah dijelaskan dengan jelas dalam Al-Quran dan Al-Sunnah. Sebagaimana Firman Allah SWT dalam QS. Al-Baqarah/2, Bagian: 278.

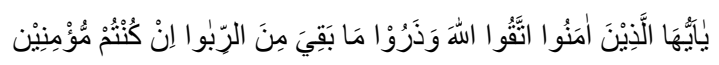

Terjemahnya:

"Wahai orang-orang yang beriman, bertakwalah kepada Allah dan tinggalkan sisa riba (yang belum dipungut) jika kamu orang-orang yang beriman. (QS Al-Baqarah/ $2: 278) " .15$

Tafsir Ringkas:

Oh ya siapa yang menerima. Takutlah kepada Allah dengan menjauhi disiplin Allah antara lain karena perbuatan riba, dan meninggalkan sisa riba yang belum terkumpul sampai datangnya pengingkaran terhadap riba. Anda benar-benar seorang penganut jika Anda stabil seperti yang wajar bagi Anda dan perbuatan. Jika kamu tidak mengerjakannya, yang merupakan hal yang diminta, maka kamu mengumpulkan sisa riba yang belum kamu kumpulkan, maka, kemudian yakinlah bahwa akan terjadi sesuatu yang dahsyat dari Allah dan Rasul-Nya., mengingat bencana dan tipu daya untuk dunia ini, dan siksaan yang menyiksa di alam semesta yang besar. Namun, jika Anda melakukannya, yaitu saat ini tidak melakukan pertukaran riba dan melakukan latihan ilahi, jangan mengumpulkan riba yang belum dikumpulkan, maka pada saat itu konflik tidak akan berlanjut, benar. diberitahu bahwa Anda memenuhi syarat untuk properti Anda. Dengan cara ini, Anda tidak melakukan kecurangan atau kerusakan dengan membiarkan mereka membayar apa yang mereka dapatkan dan tidak dilanggar atau disakiti karena mereka membayar berapa pun kewajiban yang mereka dapatkan.

Selanjutnya pada (QR. Ali Imran/ 3:130)

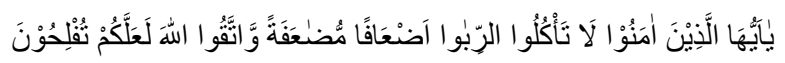

Terjemahnya:

${ }^{15}$ Departemen Agama RI, Al-Qur'an dan Terjemahannya, (Jakarta: Institut Ilmu AlQur'an (IIQ)), h. 47 
"Wahai orang-orang yang beriman! Janganlah kamu memakan riba dengan berlipat ganda dan bertakwalah kepada Allah agar kamu beruntung".16

Tafsir Ringkas:

Kaum kafir membiayai perang, termaksud perang uhud, dengan harta yang mereka peroleh dengan cara riba. Oleh karena itu Allah mengingatkan, wahai orang-orang yang beriman. Janganlah kamu memakan riba, yaitu mengambil nilai tambah dari pihak yang berhutang dengan berlipat ganda sebagaimana pada masyarakat jahiliah, maupun menambah dari pokok harta walau tidak berlipat ganda, dan bertakwalah kepada Allah antara lain dengan meninggalkan riba, agar kamu beruntung di dunia dan di akhirat.

Hadits

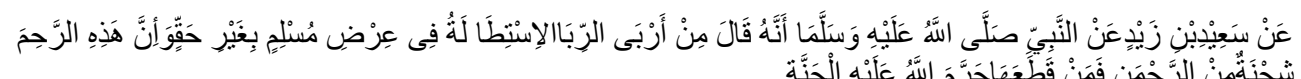

Terjemahnya:

"Dari Sa'id bin Zaid dari Nabi shallallahu 'alaihi wasallam, bahwa beliau bersabda: "Sesungguhnya riba yang paling buruk adalah merusak kehormatan seorang muslim tanpa hak, dan sesungguhnya rahim dijalinkan oleh Ar Rahman, barangsiapa yang memutuskannya niscaya Allah mengharamkan baginya syurga. (Ahmad, bab Musnad Sa'id bin Zaid, no 1564)".

\section{PENUTUP}

A. Kesimpulan

1. Dalam pengertian umum arisan atau tabungan bersama (company saving) merupakan perkumpulan uang yang diundi secara berkala. Praktek arisan beranak ini menggunakan akad hutang-piutang. Yang beruntung dan yang berpiutang yaitu mereka yang mendapatkan undian arisan lebih awal adalah sebagai yang berhutang (kreditur) karena mereka harus membayar uang setoran beserta tambahannya setiap bulan kepada mereka yang belum mendapatkan. Dan yang berpiutang (debitur) adalah anggota yang mendapat arisan lebih akhir karena mereka memberikan pinjaman kepada anggota yang mendapat undian terlebih dahulu.

2. Tambahan dalam praktek arisan beranak tersebut sama dengan riba dalam hutang-piutang. Karena terdapat tambahan yang telah dipersyaratkan pada awal di dirikan arisan, tambahan tersebut meningkat sedikit demi sedikit setiap bulannya. Maka dalam hal ini praktek arisan tersebut haram karena terdapat unsur riba didalamnya.

\section{B. Implikasi Penelitian}

1. Alangkah baiknya tambahan dalam praktek arisan beranak ini menggunakan akad mudharabah. Setiap anggota mendapat bagian dari keuntungan pekerjaan yang mendapatkan undian terlebih dahulu.

2. Hanya memberikan tambahan yang kecil apabila bahan pokok mengalami kenaikan agar tidak memberatkan para pelaku arisan dengan tambahan yang terus meningkat setiap bulan.

\footnotetext{
${ }^{16}$ Departemen Agama RI, Al-Qur'an dan Terjemahannya, h. 66
} 


\section{DAFTAR PUSTAKA}

Afzalurrahman, Doktrin Ekonomi Islam, (Yogyakarta: Dana Bhakti Wakaf, 1995). h. 189.

Ahmad Azhar Basyr, Asas-asas Hukum Muamalat, edisi revisi, Yogyakarta Perpustakaan Fakultas Hukum UII,1993

Departemen Agama RI, Al-Qur'an dan Terjemahannya, Jakarta: Institut Ilmu Al-Qur'an (IIQ).

Dwi Widodo, Aparat Desa Sidorejo, Kec. Wonomulyo, Wawancara oleh penulis di Desa Sidorejo, 11 juni 2021

Martini, Ketua Praktek Arisan Beranak Desa Sidorejo, Kec. Wonomulyo, Wawancara oleh penulis di Desa Sidorejo, 20 April 2021.

Ngadiem, Anggota Praktek Arisan Beranak Desa Sidorejo, Kec. Wonomulyo, Wawancara oleh penulis di Desa Sidorejo, 27 April 2021.

Saifuddin, J-Alif Jurnal Penelitian Hukum Ekonomi Syariah, Praktek Bangung Rumah Tinggal Dengan Sistem Arisan Dalam Tinjauan Hukum Islam, Lembaga Penelitian dan Pengabdian Masyarakat Universitas Al Asyiariah Mandar,2017.

Sulami, Anggota Praktek Arisan Beranak Desa Sidorejo, Kec. Wonomulyo, Wawancara oleh penulis di Desa Sidorejo, 26 April 2021.

Tiah, Anggota Praktek Arisan Beranak Desa Sidorejo, Kec. Wonomulyo, 26 April 2021.

Usman Qultubi, Tokoh Agama Desa Sidorejo, Kec. Wonomulyo, Wawancara oleh penulis di Desa Sidorejo, 11 juni 2021. 
Vol. 6, No. 1, Mei 2021

p-ISSN: 2541-5212 | e-ISSN: 2541-5220

J-ALIF Jurnal Penelitian Hukum Ekonomi Syariah dan Sosial

Budaya Islam 